\title{
KANGAROO MOTHER CARE PADA BAYI BERAT LAHIR RENDAH : SISTEMATIK REVIEW
}

\author{
Kangaroo Mother Care In Low Baby Weight: A Systematic Review
}

\author{
Tetti Solehati1, Cecep Eli Kosasih², Yulia Rais³, Noor Fithriyah,4 \\ Darmayanti5, Neneng Ratnanengsih Puspitasari6 \\ 1,2,3,4,5,6 Fakultas Keperawatan, Universitas Padjadjaran \\ Email: tetti. solehati@unpad.ac.id
}

\begin{abstract}
ABSTRAK
Masa bayi merupakan masa pertama dalam fase kehidupan seseorang, dimana pada masa ini memerlukan adaptasi terhadap lingkungan. Bayi Berat Lahir Rendah adalah bayi baru lahir yang memiliki berat saat lahir kurang dari 2500 gram. Prevalensi BBLR diperkirakan 15\% dari seluruh kelahiran di dunia dan lebih sering terjadi di negara berkembang atau dengan sosio ekonomi rendah. Angka kematian BBLR 35x lebih tinggi di banding pada bayi dengan berat lahir lebih dari 2500 gram. untuk mensistensis penelitian-penelitian secara empiris sehingga dapat mengidentifikasi perawatan dengan metode kangaroo mother care pada BBLR. Sistematik review ini dilakukan melaui tahapan : membuat pertanyaan penelitian, mencari sumber data dan ektraksi serta seleksi artikel. Pencarian artikel menggunakan database elektronik yaitu google scholar, Pub Med, SINTA, Kandaga, Nejm, Science Direct dengan kata kunci yang digunakan dalam bahasa Indonesia dan bahasa inggris adalah "BBLR" atau "Low birth weight", "Kangaroo Mother Care (KMC)". Kriteria inklusi artikel yang diambil yaitu yang diplubikasikan full text, dalam rentang waktu 2014-2018, jenis penelitian kuantitatif, kriteria peneliti minimal S1 Keperawatan, artikel yang memiliki konten utama intervensi Kangaroo Mother Care untuk perawatan BBLR. Hasil pencarian ditemukan 1.625 artikel pada Google Scholar 201 artikel, NEJM 12 artikel, Pub Med 633 Artikel, dan Science Direct 779 artikel. Setelah disesuaikan dengan kriteria inklusi maka artikel yang tersisa sebanyak 8 artikel. KMC dalam perawatan BBLR berpengaruh signifikan terhadap peningkatan respon fisiologis BBLR. Disarankan KMC sebagai terapi untuk perawatan BBLR yang dapat dilakukan oleh ibu secara langsung, tanpa biaya dengan pemberian pendidikan kesehatan oleh tenaga kesehatan terlebih dahulu.
\end{abstract}

\section{Kata Kunci : BBLR, kangaroo mother care, perawatan}

\begin{abstract}
Babyhood reaches the first phase in a person's life phase, where it is now adapted to the environment. Low Birth Weight is a newborn who weighs less than 2500 grams. LBW Prevalence It is estimated that 15\% of the world and more often occurs in developing countries or with low socio-economic. The mortality rate of $B B L R$ is 35x higher in infants weighing more than 2500 grams. to empirically research the empirical studies can be done by the method of mother care kangaroo on LBW. This systematic review is done through stages: creating research questions, searching for data and extraction as well as full articles. Articles in using electronic databases are google scholar, Pub Med, SINTA, Kandaga, Nejm, Direct Science with keywords that are Indonesian and English is "BBLR" or "Low Birth Weight", "Kangaroo Mother Care (KMC)". The inclusion criteria of the articles used are fully texted, within 2014-2018, the type of quantitative research, the nursing researcher's minimum criterion, the article that has the main content of Kangaroo Mother Care for LBW care. Search results found 1,625 articles on Google Scholar 201 articles, NEJM 12 articles, Pub Med 633 Articles, and Direct Science 779 articles. After adjusting for the problem, you will find the remaining 8 articles. $K M C$ in the treatment of LBW need to be significant to the increasing physiological response of LBW. Dark $K M C$ as a therapy for LBW care that can be done by the mother directly, at no cost by providing health services by health personnel first.
\end{abstract}

Keywords : BBLR, kangaroo mother care, care

\begin{tabular}{lll}
\hline Sekretariat & \multicolumn{2}{l}{ Article History: } \\
Editorial: Kampus FKM UNISMUH PALU - Palu 94118, & $\Rightarrow$ & Received 9 Mei 2018 \\
$\quad$ Sulawesi Tengah, Indonesia & $\Rightarrow$ & Revised 23 Mei 2018 \\
Telp/HP: +6281245936241, Fax (0451) 425627 & $\Rightarrow$ & Accepted 7 Juni 2018 \\
E-mail: jurnal.mppki@gmail.com & $\Rightarrow$ & Available online 25 Juni 2018 \\
OJS: http://jurnal.unismuhpalu.ac.id/index.php/PJKM &
\end{tabular}




\section{PENDAHULUAN}

Bayi merupakan anak yang berada pada rentang usia 0-12 bulan. Masa bayi merupakan dalam fase pertama kehidupan manusia, dimana pada masa ini memerlukan adaptasi terhadap lingkungan. BBLR adalah bayi baru lahir yang memiliki berat saat lahir kurang dari 2500 gram. Prevalensi Bayi Berat Lahir Rendah diperkirakan $15 \%$ dari seluruh kelahiran di dunia dan lebih sering terjadi di negara-negara berkembang atau dengan sosio ekonomi rendah. Angka kematian BBLR 35x lebih tinggi di banding pada bayi dengan berat lahir lebih dari 2500 gram (Profil Kesehatan Indonesia, 2013). Menurut WHO dalam Bebasari, Agonwardi dan Nandiati (2010) BBLR ini dapat meningkatkan mortalitas, morbiditas, disabilitas neonatus, bayi dan anak serta memberikan dampak jangka panjang terhadap kehidupannya di masa depan.

BBLR ini akan menimbulkan dampak dalam jangka panjang dimasa yang akan datang yang akan mempengaruhi kualitas generasi penerus bangsa. Oleh karena itu penatalaksaan umum pada BBLR menjadi hal yang sangat diperlukan untuk mencegah terjadinya komplikasi. Penatalaksaan umum yang dapat diberikan pada bayi dengan BBLR yaitu mempertahankan suhu tubuh, pengaturan dan pengawasan intake nutrisi, pencegahan infeksi, penimbangan berat badan, pemberian oksigen dan pengawasan jalan nafas.

Salah satu tindakan yang dapat diberikan pada bayi-bayi dengan BBLR yaitu dengan perawatan metode kangaroo mother care (KMC). Metode ini merupakan terapi tanpa biaya yang dapat dilakukan ibu karena tidak semua bayi dengan BBLR mampu mendapatkan pelayanan kesehatan menggunakan teknologi yang maju. Biasanya hal tersebut disebabkan karena faktor sosial ekonomi yang rendah, geografis, transportasi dan komunikasi (Bebasari, Agonwardi dan Nandiati, 2010). KMC pertama kali diterapkan di Bogota, Colombia dengan tujuan mengurangi angka kesakitan dan kematian yang tinggi pada BBLR akibat terbatasnya sumber daya di ruang NICU. Bayi dengan BBLR yang mendapat perawatan KMC akan mempunyai pengalaman psikologis dan emosional lebih baik karena dengan metode ini bayi akan memperoleh kehangatan serta lebih dekat dengan ibu sehingga mampu meningkatkan kualitas hidup bayi (Maryunani, 2013).

\section{METODE PENELITIAN}

Penyusunan sistematik review ini terdiri dari beberapa tahapan diantaranya adalah :

Membuat Pertanyaan Penelitian

Sebelum memulai sistematik review, tim melakukan diskusi untuk membahas tujuan sistematik review dan merumuskan pertanyaan penelitian untuk memandu pencarian literature : Adapun pertanyaan yang kami susun adalah : Bagaimana pengaruh Kangaroo Mother Care (KMC) terhadap perawatan Bayi Berat Lahir Rendah (BBLR).

\section{Mencari Sumber Data dan Ektraksi}

Setelah mengembangkan pertanyaan penelitian, tahap selanjutnya adalah berkonsultasi dengan dosen pembimbing, yang memberikan masukan pada pemilihan istilah dan basis data pencarian yang paling relevan untuk menjawab pertanyaan penelitian. Pada awal pencarian reviewer dengan sengaja mencari secara luas untuk mengambil banyak artikel penelitian yang relevan. Selanjutnya reviewer mengkhususkan pada pencarian beberapa artikel jurnal penelitian yang diplubikasi melalui database elektronik. Seperti Google Scholar, Pub Med, Sinta, NEJM, dan Science Direct dengan kata kunci (keyword) yang digunakan adalah jurnal berbahasa Indonesia dan Inggris yaitu BBLR atau Low Birth Weight, Kangaroo Mother Care. Hasil pencarian ditemukan 1.625 artikel pada Google Scholar 201 artikel, NEJM 12 artikel, Pub Med 633 Artikel, dan Science Direct 779 artikel.

Seleksi artikel

Tahap selanjutnya adalah reviewer melakukan seleksi artikel berdasarkan spesifikasi KMC pada perawatan BBLR yaitu meliputi : Perawatan fisik (suhu, respirasi), perawatan Nutrisi (Peningkatan Berat Badan), dan perawatan kulit (Lowdermilk, 2013). Selanjutnya dilakukan seleksi kembali berdasarkan kriteria inklusi yaitu : 1) artikel yang dipublikasikan full text, 2) artikel yang dipublikasikan dalam rentang waktu 2014$2018,3)$ jenis penelitian kuantitatif, 4) kriteria peneliti minimal S1 Keperawatan, 5) artikel yang memiliki konten utama intervensi 
Kangaroo Mother Care, untuk perawatan BBLR. Selain itu, alasan umum untuk tidak menggunakan artikel dalam penelitian ini adalah kejelasan prosedur dalam penelitian dan penjelasan sample yang digunakan, maka artikel yang dapat menjawab pertanyaan penelitian sebanyak 8 artikel.

\section{HASIL}

Berdasarkan hasil screening dari 8 artikel yang terpilih dari tahun 2014-2018, seluruh artikel yang dianalisis menggunakan metode kuantitatif, dengan design penelitian Quasy eksperimental, seluruh sampel dalam penelitian adalah bayi dengan berat lahir rendah yang dilakukan intervensi Kangaroo Mother Care.

Hasil penelitian dari beberapa artikel menunjukkan bahwa perawatan metode kangaroo mother care memberikan pengaruh terhadap respon fisiologis pada Bayi Berat Lahir Rendah, yaitu dalam mempertahankan suhu tubuh, peningkatan berat badan, peningkatan saturasi 02 dan stabilisasi nadi. Menurut Astuti, Mutoharoh dan Priyanti, tahun 2015 pada 28 bayi, melalui metode kuasi eksperimental dengan pre dan post test control group desain, tentang pengaruh penerapan KMC dengan peningkatan berat badan BBLR. Terjadi peningkatan berat badan pada bayi yang mendapatkan perawatan KMC yaitu sebesar 1071,43 gram. hal ini berarti ada pengaruh perawatan KMC terhadap peningkatan berat badan bayi BBLR.

Penelitian ini didukung pula oleh penelitian sebelumnya yang dilakukan oleh Putri, Gusmila (2014) mengatakan bahwa terdapat perbedaan rata-rata berat badan bayi sebelum dan sesudah perawatan dengan metode kanguru di ruang perinatologi RSUD Dr. Achmad Mochtar Bukittinggi. Penelitian yang dilakukan dengan pendekatan one group pretest posttest ini berdasarkan ratarata berat bayi sebelum perawatan metode kanguru dan sesudah perawatan metode kanguru yaitu 28,30 gram dengan standar deviasi 3,093 . Penelitian yang dilakukan ini dilaksanakan selama 2 minggu. Penelitian lain oleh Lestari, Septiwi dan Ningiswati (2014) tentang pengaruh KMC terhadap stabilitas suhu tubuh BBLR di ruang Peristi RSUD Kebumen menunjukkan bayi berat badan lahir rendah yang diberikan perlakuan perawatan metode kanguru/kangaroo mother care memiliki peluang mengalami suhu tubuh normal 0,350 kali lebih tinggi dibandingkan responden yang tidak diberikan perlakuan perawatan metode kanguru/kangaroo mother care.

Perawatan dengan metode kanguru pada BBLR kemudian dilakukan kembali oleh Bebasari, Agonwardi dan Nandiati tahun 2017 bahwa ada pengaruh perawatan metode kanguru terhadap kenaikan berat badan pada BBLR di ruang perinatologi RSUD Dr. Rasidin Padang tahun 2017 dengan $p$ value 0,000 . Penelitian ini dilaksanakan selama 6 hari berturut-turut terhadap 15 orang ibu yang memiliki bayi BBLR diruang perinatologi yang keseluruhannya merupakan kelompok intervensi karena desain yang digunakan yaitu pre test and post test one group design.

Penelitian lain telah dilakukan dimana terdapat pengaruh perawatan metode kanguru terhadap stress fisilogis pada bayi berat lahir rendah sebelum dan sesudah dilakukan perawatan dengan metode kanguru di RSUD Sukoharjo dimana nilai $p$ value nya 0,000 . Penelitian ini dilaksanakan terlebih dahulu dengan pre test dimana dilakukan pengukuran fisiologis bayi (suhu tubuh, saturasi oksigen, denyut jantung bayi) sebelum intevensi metode kanguru lalu dicatat di lembar observasi. Pada saat pelaksanaan penelitian dilakukan selama minimal 1 jam dan lakukan pengukuran suhu, saturasi oksigen dan denyut nadi setelah selesai pelaksanaan PMK. Adapun pelaksanaan PMK selama 3 hari. Peningkatan respon fisiologis bayi setelah dilakukan perawatan metode kanguru disebabkan karena mayoritas bayi sebelum perawatan metode kanguru respon fisiologisnya masih rendah. Artinya dengan perawatan metode kanguru ini dapat menstabilkan respon fisiologis bayi BBLR.

Pengaruh perawatan metode kangguru terhadap berat badan sebelum dilakukan perawatan metode kanguru yaitu 1641 dengan standar deviasi 541,13 dan standar eror 241,9. Berat badan sesudah dilakukan perawatan metode kanguru yaitu 1496 dengan standar deviasi 406,485 dan standar eror 181,786. Terdapat pengaruh berat badan bayi baru lahir rendah yang terpasang alat medis terhadap perawatan metode kanguru dengan nilai $p=0,000$ 
$(\mathrm{p}<0,05)$ yang artinya ada perbedaan yang signifikan antara berat badan bayi pada sebelum dilakukan perawatan metode kanguru dengan sesudah dilakukan perawatan metode kanguru. Sebanyak 11 bayi dengan BBLR di RSI Sakinah Mojokerto yang diberikan metode kangguru selama satu bulan didapatkan adanya peningkatan berat badan yang berkisar antara 50-350 gram.

\section{PEMBAHASAN}

Bayi dengan berat badan lahir rendah (BBLR) adalah bila berat badannya kurang dari 2.500 gr tanpa memandang masa gestasi. BBLR termasuk faktor utama dalam peningkatan mortalitas, morbiditas dan disabilitas neonatus, bayi dan anak serta memberikan dampak jangka panjang terhadap kehidupannya di masa depan. Oleh karena perlu adanya perawatan yang diberikan terhadap bayi dengan BBLR (Sembiring, 2017).

Metode KMC merupakan perawatan suportif yang dilakukan dengan meletakkan bayi diantara kedua payudara ibu sehingga terjadi kontak langsung kulit ibu dan kulit bayi. Menurut Bobak (2005) KMC merupakan praktik menggendong bayi prematur yang hanya mengenakan popok dan topi pada dada telanjang ibu. Metode KMC ini memiliki keuntungan-keuntungan yang terdiri dari : meningkatkan hubungan emosi ibu dan anak, menstabilkan suhu tubuh, denyut nadi jantung dan pernafasan bayi, meningkatkan pertumbuhan dan berat badan bayi lebih baik, mengurangi stress pada ibu dan bayi, mengurangi lama menangis pada bayi, memperbaiki emosi ibu dan bayi serta meningkatkan produksi ASI (Suriviana, 2009). Selain itu manfaat yang didapat dengan metode KMC ini menurut Maryunani (2013) yaitu pemakaian kalori berkurang, mengurangi kejadian infeksi sehingga dapat menurunkan resiko kematian dini pada bayi, meningkatkan rasa nyaman pada saat bayi tidur, menurunkan stres pada bayi karena bayi merasa aman dan nyaman, sehingga menurunkan respon nyeri pada bayi.

Dengan menggunakan metode KMC, kestabilan suhu BBLR dapat dijaga karena pada metode ini bayi ditempatkan melekat dengan perut ibu yang berfungsi sebagai thermoregulator. Mekanisme lain yang terjadi adalan kontak kulit dengan kulit antara ibu dengan bayi dapat meningkatkan hormone kortisol pada bayi yang berdampak pada kualitas tidur bayi meningkat. Selain meningkatkan BB dan menstabilkan suhu, KMC juga dapat meningkatkan saturasi oksigen karena posisi bayi yang tegak dapat mengoptimalkan fungsi respirasi yang dipengaruhi oleh gravitasi bumi sehingga berefek pada ventilasi dan perfusi bayi. Hal tersebut didukung oleh pernyataan bahwa dengan metode KMC mampu mencegah hipotermia pada bayi dengan menurunkan kebutuhan metabolic dan oksigen pada bayi.

Posisi yang nyaman pada metode KMC akan memberikan impuls pada hypothalamus untuk merspons kelenjar medulla adrenal untuk menekan pengeluaran hormone epineprin dan norepineprin atau pelepasan katekolamin dalam darah berkurang denyut jantung menurun dan oksigen berkurang, yang akhirnya frekuensi bernafas menjadi lambat.

Selain memberikan manfaat untuk bayi dan ibu nya, metode KMC ini juga memberikan manfaat untuk ayah, petugas kesehatan dan fasilitas kesehatan. Menurut Maryunani (2013) manfaat KMC untuk ayah yaitu ayah memiliki peranan yang lebih besar dalam perawatan bayinya, serta meningkatkan hubungan antara ayah-bayinya. Untuk petugas kesehatan KMC ini memberikan manfaat berupa efisiensi tenaga petugas kesehatan, beban kerja petugas berkurang, petugas kesehatan dapat melakukan tugas lainnya. Sedangkan untuk fasilitas pelayanan kesehatan yaitu lama rawat perawatan lebih pendek sehingga bayi bisa lebih cepat pulang, efisiensi anggaran.

Tindakan KMC lebih lama mempunyai efek positif terhadap lama menyusui dan suhu bayi dalam rentang normal sehingga terjadi peningkatan berat badan bayi. Bayi yang menyusu ke ibu lebih lama akan membuat bayi merasa tenang dan nyaman sehingga bayi mendapatkan suplai ASI yang mencukupi serta energi yang diperoleh tubuh hanya difokuskan untuk pertumbuhan. Bayi yang diberikan KMC mempunyai suhu tubuh relatif normal, denyut jantung dan pernafasan teratur, tidur lebih lama dan sedikit menangis. KMC pada bayi baru lahir akan menyebabkan peningkatan kadar glukosa yang menyebabkan metabolisme sel baik sehingga pertumbuhan sel menjadi lebih baik.

KMC juga dapat meningkatkan suhu 
tubuh bayi daripada bayi yang berada didalam inkubator sehingga dapat mencegah stres dingin pada bayi. Stres dingin yaitu kejadian yang dapat terjadi pada bayi dimana suhu tubuh bayi menurun dan mengalami hipotermia. Pemberian KMC ini meningkatkan berat badan bayi namun tidak menurunkan lama tinggal dirumah sakit dan mampu pertahankan suhu tubuh bayi.

Peningkatan berat badan terjadi juga karena meningkatnya hubungan bayi dan ibu dimana bayi mempunyai waktu yang lebih lama untuk merasakan sentuhan yang dapat mengurangi pengeluran katekolamin dalam darah sehingga menurunkan stres fisiologis janin. KMC meningkatkan bounding ibu dan bayi serta merupakan intervensi terapeutik untuk meningkatkan kedekatan ibu, mempromosi perilaku alami untuk stimulasi pertumbuhan dan perkembangan (Smith, 1996, Dodd, 2005 dalam Arifah \& Wahyuni, 2013).

Keberhasilan dalam peningkatan berat badan bayi setelah dilakukan perawatan metode kanguru dipengaruhi oleh beberapa faktor salah satunya kemampuan bayi dalam menghisap ASI. ASI merupakan komponen yang sangat penting dalam pertumbuhan bayi. ASI yang diminum bayi harus sesuai kebutuhan dari bayi tersebut sehingga kebutuhan nya tercukupi. Dalam perawatan metode kanguru ini frekuensi ibu dalam memberikan ASI lebih teratur dan tepat waktu sehingga membantu bayi dalam memenuhi kebutuhan akan nutrisi dan cairannya. Metode kanguru ini membantu kemampuan bayi dalam menyusui karena reflek menghisap bayi akan selalu terasah dan terlatih serta hubungan ibu dan bayi akan lebih baik karena terjadi kontak langsung yang diberikan ibu kepada bayinya.

Penambahan berat badan bayi dipengaruhi juga oleh usia bayi, pada minggu pertama kelahiran pertambahan berat badan bayi pada perawatan bayi normal belum optimal, begitu pun pada perawatan metode kanguru. Namun metode kanguru mampu membantu dalam menstabilkan fungsi fisiologis bayi (suhu tubuh, pernapasan, denyut nadi) yang akan membantu dalam metabolisme tubuh (Putri, 2014), karena dalam metode kangaroo posisi bayi langsung berlekatan dengan ibu sehingga kestabilan suhu bayi terjaga dan mencegah dari resiko hipotermi.
Keberhasilan metode KMC dipengaruhi oleh pengetahuan dan pendidikan ibu, sikap ibu, dan dukungan keluarga serta fasilitas dan pelayanan kesehatan yang diberikan. Pengetahuan ibu ini dipengaruhi oleh pendidikan ibu dimana semakin tinggi tingkat pendidikan seseorang maka semakin tinggi pengetahuan tentang sesuatu, begitupun dengan pengetahuan ibu tentang KMC. Pengetahuan yang baik tentu akan mempengaruhi sikap ibu. Oleh karena itu jika ibu memiliki pengetahuan yang baik maka sikap yang ditunjukkan oleh ibu adalah sikap positif. Artinya jika pengetahuan ibu baik maka ibu akan memiliki sikap mendukung terhadap perawatan BBLR dengan metode KMC ini.

Faktor lain yang mempengaruhi pelaksanaan KMC adalah dukungan keluarga. Dukungan keluarga ini dapat diberikan baik oleh pasangan maupun oleh orang tua atau anggota keluarga yang lain. Berdasarkan penelitian yang dilakukan oleh Lidya (2018) bahwa keluarga memegang peranan yang penting dalam asuhan bayi baru lahir, dimana keluarga mempunyai potensi untuk menentukan asuhan yang terbaik untuk bayinya. Oleh karena keluarga harus dilibatkan dalam pemberian asuhan pada bayi baru lahir terutama yang mengalami BBLR sehingga perawatan metode KMC ini dapat berhasil.

\section{KESIMPULAN DAN SARAN}

Berdasarkan hasil pembahasan diatas dapat disimpulkan bahwa terdapat pengaruh KMC terhadap BBLR. Oleh karena itu merekomendasikan KMC sebagai terapi untuk perawatan Bayi Berat Lahir Rendah yang dapat dilakukan oleh ibu secara langsung, tanpa biaya dengan pemberian pendidikan kesehatan oleh tenaga kesehatan terlebih dahulu.

\section{DAFTAR PUSTAKA}

Arifah, Siti., \& Wahyuni, Sri. 2013. Pengaruh Kangaroo Mother Care (KMC) Dua Jam dan Empat Jam Per Hari terhadap Kenaikan Berat Badan Lahir Rendah Bayi Preterm di RS PKU Muhammadiyah Surakarta. Prosiding Seminar Ilmiah Nasional Kesehatan: 35-41

Astuti, Dyah P, Mutoharoh, siti, dan Priyanti, Rina 2010. Pengaruh Penerepan 
Metode Kanguru Dengan Peningkatan Berat Badan Bayi Berat Lahir Rendah (BBLR) Di Rumah Sakit PKU Muhammadiyah Gombong.

Atik, Nur S., Nugraheni, Sri. A., \& Cahyo, K.usyogo. 2016. Analisis Implementasi Program Perawatan Metode Kanguru (PMK) dan Partisipasi Pasien pada Pelayanan Kesehatan Bayi Berat Lahir Rendah (BBLR)(Studi pada Pasien di Rumah Sakit Mardi Rahayu Kudus). Jurnal Manajemen Kesehatan Indonesia, 4(2), 98-108.

Bebasari, Mardiani, \& Agonwardi, Agonwardi. 2017. Pengaruh Perawatan Metode Kanguru Terhadap Kenaikan Berat Badan Pada Bayi Berat Badan Lahir Rendah Di Ruang Perinatologi Rsud Dr. Rasidin Padang Tahun 2017. Jik-Oktober Volume 1 No 1 Tahun 2017, 1(1), 32-38.

Bobak, I.M., Lowdermilk, D.L. \& Jensen, M.D, 2005. Buku ajar keperawatan maternitas. edisi 4. Jakarta : EGC.

Heraswati, Rahayu, Sri., \& Khafidhoh, Nur. 2015. Efektifitas Perawatan Metode Kanguru Intermitten Dalam Peningkatan Berat Badan Bayi Berat Lahir Rendah di RSUD Tugurejo Semarang Tahun 2013. JURNAL KEBIDANAN, 2 (4), 10-15.

Lestari, Sr A, Septirini, Cahyu, dan Iswati, Ning. 2014. Pengaruh Perawatan Metode Kanguru/Kangaroo Mother Care Terhadap Stabilitas Suhu Tubuh Bayi Berat Lahir Rendah Di Ruang Peristi RSUD Kebumen.

Lidya. (2018). Hubungan Dukungan Keluarga Dan Sikap Ibu Dengan Pelaksanaan Perawatan Metode Kanguru Pada Bayi Berat Lahir Rendah Di Ruang Perinatologi Rsud H. Abdul Manap Kota Jambi Tahun 2016. Jurnal Ilmiah Universitas Batanghari Jambi, 18(1), 195-207.

Maryunani, Anik. 2013. Asuhan bayi dengan berat badan lahir rendah (BBLR). Jakarta : Trans Info Media.

Mutmainah, Hartini, dan Solechan. 2015. Efektivitas Pijat Bayi Terhadap Berat Badan Bayi Usia 0-3 Bulan Di Smc Rs Telogorejo.

Nani, Desiyani., Utami, Oktariani., \& Purwanti, A.cik Y. 2013. The Classic Mozart Music Therapy on Basal Metabolic
Rate (BMR) in Premature Infants at Perinatology of Banyumas Hospital. Jurnal Ilmiah Kesehatan Keperawatan, $9(3)$.

Nur, Rosma, Arifuddin, Adhar., \& Novila, Redita. 2016. Analisis Faktor Risiko Kejadian Berat Badan Lahir Rendah Di Rumah Sakit Umum Anutapura Palu. Preventif: Jurnal Kesehatan Masyarakat, 7(1).

Putri, Yelmi R., \& Gusnila, Elharisda. 2017. Pengaruh Perawatan Metode Kanguru terhadap Perubahan Berat Badan Bayi Lahir Rendah. Jurnal Ipteks Terapan, 9 (1).

Rahmawati, Anita., Theresia, Endah. M., \& Purnamaningrum, Yuliasti E. 2015. Pengaruh Musik Keroncong selama Pelaksanaan Kangaroo Mother Care terhadap Respons Fisiologis dan Lama Rawat Bayi dengan Berat Badan Lahir Rendah. Kesmas: National Public Health Journal, 10(2), 93-98.

Sembiring, JB. Buku Ajar Neonatus, Bayi, Balita, Anak Pra Sekolah Ed. 1, Cet. 1. Yogyakarta : Deepublish, Mei-2017.

Surasmi, Asrining, Dkk. 2003. Perawatan bayi resiko tinggi. Jakarta : EGC.

Suriviana. 2005. Metode Kanguru Untuk Merawat Bayi Prematur. Available on http://www.Infoibu.com. 
Artikel yang ditemukan dalam Database elektronik Google Scholar, Pub Med, NEJM dan Science Direct, berdasarkan keywords $\mathrm{N}=1.625$

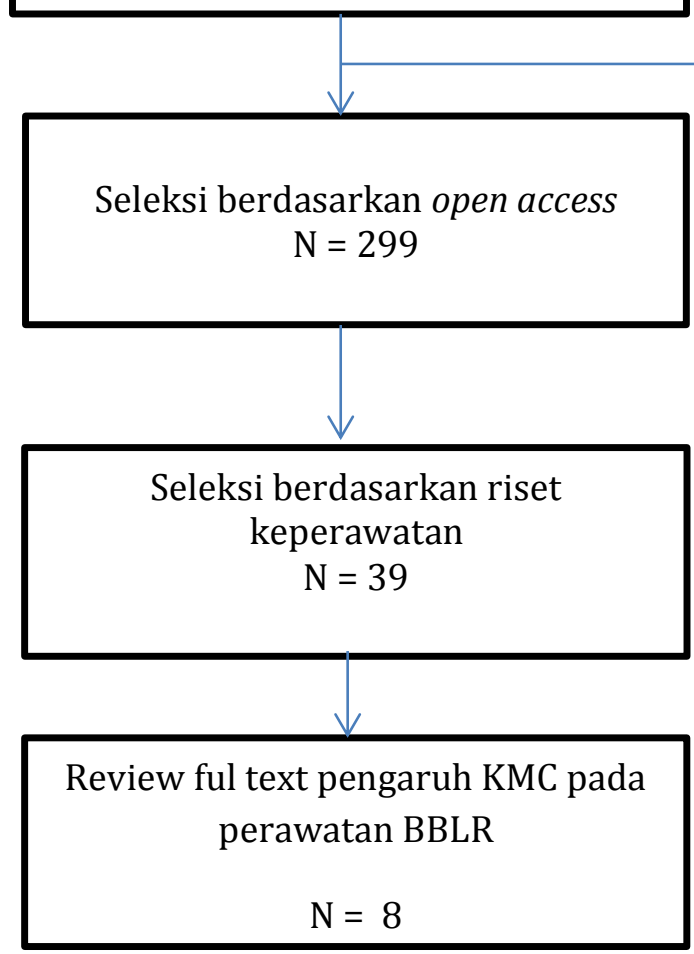

Artikel

Tahun 2014-2018 $\mathrm{N}=675$

Gambar 1. Tahapan Penyusunan Sistematik Review 


\begin{tabular}{|c|c|c|c|c|c|c|c|c|c|}
\hline $\begin{array}{c}\text { Nama } \\
\text { (Tahun) }\end{array}$ & Judul & Metode & Sampel & $\begin{array}{c}\text { Teknik } \\
\text { sampling }\end{array}$ & $\begin{array}{l}\text { Kriteria } \\
\text { Inklusi }\end{array}$ & Perlakuan & Hasil & Kesimpulan & $\begin{array}{c}\text { Instrume } \\
\mathbf{n} \\
\end{array}$ \\
\hline $\begin{array}{l}\text { Sri Abdi } \\
\text { Lestari, } \\
\text { Cahyu } \\
\text { Septiwi, } \\
\text { Ningiswati } \\
(2014)\end{array}$ & $\begin{array}{l}\text { Pengaruh } \\
\text { perawatan } \\
\text { metode } \\
\text { kanguru/K } \\
\text { MC } \\
\text { terhadap } \\
\text { stabilitas } \\
\text { suhu } \\
\text { tubuh } \\
\text { BBLR di } \\
\text { ruang } \\
\text { Peristi } \\
\text { RSUD } \\
\text { Kebumen }\end{array}$ & $\begin{array}{l}\text { quasi } \\
\text { eksperi } \\
\text { mental } \\
\text { dgn } \\
\text { pretest } \\
\text { control } \\
\text { group } \\
\text { design }\end{array}$ & $\begin{array}{l}40 \\
\text { orang } \\
\text { subjek } \\
\text { peneliti } \\
\text { an yang } \\
\text { terdiri } \\
20 \text { utk } \\
\text { kelomp } \\
\text { ok } \\
\text { interve } \\
\text { nsi dan } \\
20 \\
\text { subjek } \\
\text { untuk } \\
\text { kelomp } \\
\text { ok } \\
\text { control }\end{array}$ & $\begin{array}{l}\text { Accidental } \\
\text { Sampling }\end{array}$ & & KMC & $\begin{array}{l}\text { bayi berat badan lahir rendah } \\
\text { yang diberikan perlakuan } \\
\text { perawatan metode } \\
\text { kanguru/kangaroo mother care } \\
\text { memiliki peluang mengalami } \\
\text { suhu tubuh normal 0,350 kali } \\
\text { lebih tinggi dibandingkan } \\
\text { responden yang tidak diberikan } \\
\text { perlakuan perawatan metode } \\
\text { kanguru/kangaroo mother care. }\end{array}$ & $\begin{array}{l}\text { Ada pengaruh } \\
\text { perawatan } \\
\text { metode } \\
\text { kanguru/kangar } \\
\text { oo mother care } \\
\text { terhadap } \\
\text { stabilitas suhu } \\
\text { tubuh bayi berat } \\
\text { lahir di Ruang } \\
\text { Peristi RSUD } \\
\text { Kebumen. }\end{array}$ & $\begin{array}{l}\text { Lembar } \\
\text { observasi } \\
\text { suhu } \\
\text { tubuh bayi }\end{array}$ \\
\hline $\begin{array}{l}\text { Dyah Puji } \\
\text { Astuti, } \\
\text { Mutoharoh } \\
\text { ' Rina } \\
\text { Priyanti } \\
\text { (2015) }\end{array}$ & $\begin{array}{l}\text { Pengaruh } \\
\text { penerapan } \\
\text { metode } \\
\text { kangguru } \\
\text { dengan } \\
\text { peningkata } \\
\text { n BB BBLR } \\
\text { di RS PKU } \\
\text { Muhamma } \\
\text { dyah } \\
\text { Gombong }\end{array}$ & $\begin{array}{l}\text { Kuasi } \\
\text { eksperi } \\
\text { menPre } \\
\text { dan } \\
\text { post } \\
\text { control } \\
\text { group } \\
\text { design }\end{array}$ & $\begin{array}{l}137 \\
\text { bayi }\end{array}$ & $\begin{array}{l}\text { random } \\
\text { sampling } \\
\text { didapat } \\
\text { sebanyak } \\
28 \\
\text { responden }\end{array}$ & $\begin{array}{l}\text { BBLR } \\
\text { yaitu } \\
\text { bayi } \\
\text { berat } \\
\text { lahir dgn } \\
\text { berat } \\
1500 \quad- \\
2500 \\
\text { gram dan } \\
\text { BBLR } \\
\text { usia 10 }\end{array}$ & & $\begin{array}{l}\text { Berdasarkan hasil penelitian } \\
\text { menunjukkan bahwa terdapat } \\
\text { peningkatkan yang signifikan } \\
\text { penerapan metode kanguru } \\
\text { terhadap peningkatan berat } \\
\text { badan bayi. Hal ini dibuktikan } \\
\text { dengan uji t berpasangan pretest } \\
\text { eksperimen } \\
\text { posttesteksperimen, dengan nilai t } \\
\text { hitung > dari t tabel dan nilai } \\
\text { signifikansi lebih kecil dari } 0,05\end{array}$ & $\begin{array}{l}\text { terdapat } \\
\text { pengaruh yang } \\
\text { signifikan } \\
\text { penerapan } \\
\text { metode kanguru } \\
\text { dengan } \\
\text { peningkatan } \\
\text { berat badan pada } \\
\text { Bayi Berat Lahir } \\
\text { Rendah (BBLR) }\end{array}$ & $\begin{array}{l}\text { Lembar } \\
\text { observasi } \\
\text { berat } \\
\text { badan bayi }\end{array}$ \\
\hline
\end{tabular}




\begin{tabular}{|c|c|c|c|c|c|c|c|c|c|}
\hline $\begin{array}{c}\text { Nama } \\
\text { (Tahun) }\end{array}$ & Judul & Metode & Sampel & $\begin{array}{c}\text { Teknik } \\
\text { sampling }\end{array}$ & $\begin{array}{c}\text { Kriteria } \\
\text { Inklusi }\end{array}$ & Perlakuan & Hasil & Kesimpulan & $\begin{array}{c}\text { Instrume } \\
n\end{array}$ \\
\hline & & & & & $\begin{array}{l}\text { hari } \\
\text { Kriteria } \\
\text { ekslusi : } \\
\text { BBLR } \\
\text { yang } \\
\text { mempun } \\
\text { yai } \\
\text { komplika } \\
\text { si cacat } \\
\text { bawaan }\end{array}$ & & $\begin{array}{l}(\mathrm{p}=0,000<0,05) \text {, yang diketahui } \\
\text { rata-rata pretest sebesar } 2285,71 \\
\text { gram, pada saat posttest } \\
\text { meningkat menjadi } 3543,21 \\
\text { gram, sehingga peningkatannya } \\
\text { sebesar } 1257,50 \text { gram. }\end{array}$ & & \\
\hline $\begin{array}{l}\text { Silvia, } \\
\text { Yelmi Reni } \\
\text { Putri, } \\
\text { Elharisda } \\
\text { Gusnila } \\
(2014)\end{array}$ & $\begin{array}{l}\text { Pengaruh } \\
\text { perawatan } \\
\text { metode } \\
\text { kanguru } \\
\text { terhadap } \\
\text { perubahan } \\
\text { berat } \\
\text { badan bayi } \\
\text { lahir } \\
\text { rendah }\end{array}$ & $\begin{array}{l}\text { quasi } \\
\text { eksperi } \\
\text { mental } \\
\text { dengan } \\
\text { metode } \\
\text { pendek } \\
\text { atan } \\
\text { one } \\
\text { group } \\
\text { pretest } \\
\text { posttest } \\
\text { dilakuk } \\
\text { an } \\
\text { selama } \\
2 \\
\text { minggu }\end{array}$ & & $\begin{array}{l}\text { Purposive } \\
\text { sampling }\end{array}$ & & KMC & $\begin{array}{l}\text { Rata-rata berat bayi sebelum } \\
\text { perawatan metode kanguru dan } \\
\text { sesudah perawatan metode } \\
\text { kanguru yaitu } 28,30 \text { gram dengan } \\
\text { standar deviasi } 3,093 \text {. } \\
\text { Berdasarkan hasil analisis uji } \\
\text { paired T-test didapatkan nilai } \\
\text { p=0,000 (p<0,05) artinya Ho } \\
\text { ditolak artinya ada perbedaan } \\
\text { rata-rata berat badan bayi } \\
\text { sebelum dan sesudah perawatan } \\
\text { metode kanguru }\end{array}$ & $\begin{array}{l}\text { Ada perbedaan } \\
\text { rata-rata berat } \\
\text { badan bayi } \\
\text { sebelum } \\
\text { perawatan } \\
\text { metode kanguru } \\
\text { dan setelah } \\
\text { perawatan } \\
\text { metode kanguru }\end{array}$ & $\begin{array}{l}\text { Lembar } \\
\text { observasi } \\
\text { berat } \\
\text { badan bayi }\end{array}$ \\
\hline Mardiani & Pengaruh & quasi & Sebany & Accidental & & KMC & Berdasarkan hasil analisis rata- & Setelah & Kuesioner \\
\hline
\end{tabular}




\begin{tabular}{|c|c|c|c|c|c|c|c|c|c|}
\hline $\begin{array}{c}\text { Nama } \\
\text { (Tahun) }\end{array}$ & Judul & Metode & Sampel & $\begin{array}{c}\text { Teknik } \\
\text { sampling }\end{array}$ & $\begin{array}{c}\text { Kriteria } \\
\text { Inklusi }\end{array}$ & Perlakuan & Hasil & Kesimpulan & $\begin{array}{c}\text { Instrume } \\
\mathbf{n} \\
\end{array}$ \\
\hline $\begin{array}{l}\text { Bebasari, } \\
\text { Agonwardi } \\
\text { ' Nandiati } \\
\text { (2017) }\end{array}$ & $\begin{array}{l}\text { perawatan } \\
\text { metode } \\
\text { kanguru } \\
\text { terhadap } \\
\text { kenaikan } \\
\text { berat } \\
\text { badan } \\
\text { pada bayi } \\
\text { berat } \\
\text { badan } \\
\text { lahir } \\
\text { rendah di } \\
\text { ruang } \\
\text { perinatolo } \\
\text { gi RSUD } \\
\text { DR. } \\
\text { Rasidin } \\
\text { Padang } \\
\text { tahun } \\
\text { 2017 }\end{array}$ & $\begin{array}{l}\text { eksperi } \\
\text { ment } \\
\text { dengan } \\
\text { kenis } \\
\text { pre test } \\
\text { dan } \\
\text { post } \\
\text { test one } \\
\text { group } \\
\text { design }\end{array}$ & $\begin{array}{l}\text { ak } 15 \\
\text { orang }\end{array}$ & sampling & & & 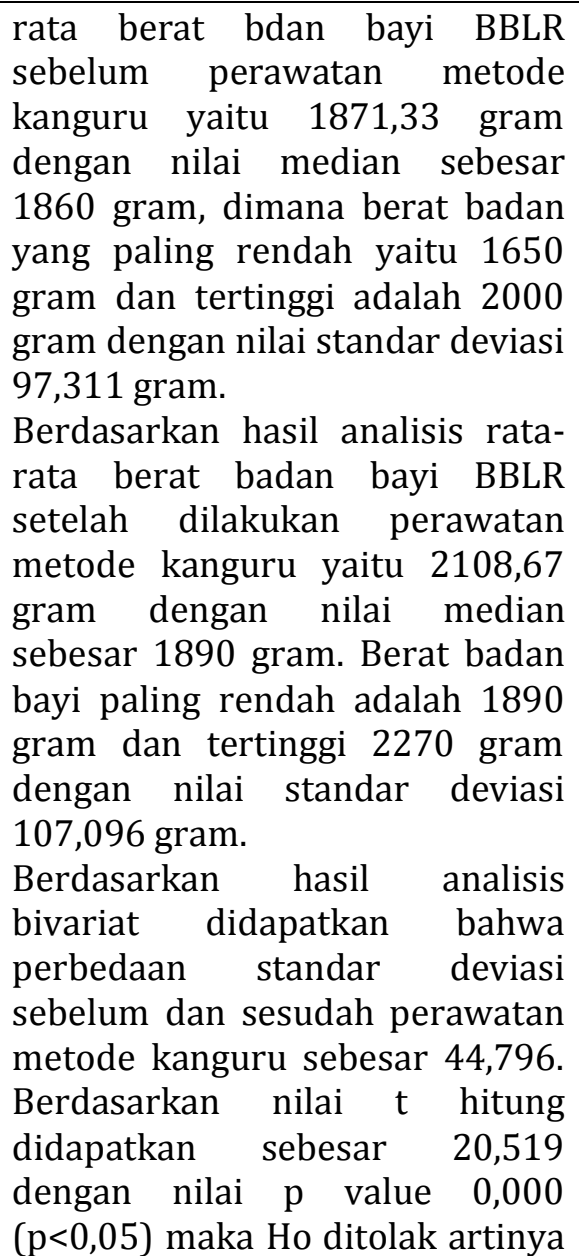 & $\begin{array}{l}\text { dilakukan } \\
\text { tindakan } \\
\text { perawatan } \\
\text { dengan metode } \\
\text { kanguru berat } \\
\text { badan pada BBLR } \\
\text { mengalami } \\
\text { perubahan yang } \\
\text { artinya } \\
\text { perawatan } \\
\text { metode kanguru } \\
\text { ini berpengaruh } \\
\text { terhadap } \\
\text { peningkatan } \\
\text { berat badan } \\
\text { BBLR }\end{array}$ & $\begin{array}{l}\text { terstruktu } \\
\mathrm{r} \& \\
\text { observasi } \\
\text { langsung }\end{array}$ \\
\hline
\end{tabular}




\begin{tabular}{|c|c|c|c|c|c|c|c|c|c|}
\hline $\begin{array}{c}\text { Nama } \\
\text { (Tahun) }\end{array}$ & Judul & Metode & Sampel & $\begin{array}{c}\text { Teknik } \\
\text { sampling }\end{array}$ & $\begin{array}{c}\text { Kriteria } \\
\text { Inklusi }\end{array}$ & Perlakuan & Hasil & Kesimpulan & $\begin{array}{c}\text { Instrume } \\
\mathbf{n}\end{array}$ \\
\hline & & & & & & & $\begin{array}{l}\text { ada pengaruh perawatan metode } \\
\text { kanguru terhadap kenaikan berat } \\
\text { badan pada bayi BBLR di ruang } \\
\text { perinatologi RSUD Dr. Rasidin } \\
\text { Padang tahun } 2017 \text {. }\end{array}$ & & \\
\hline $\begin{array}{l}\text { Endhah } \\
\text { Sulistyowa } \\
\text { ti (2015) }\end{array}$ & $\begin{array}{l}\text { Pengaruh } \\
\text { perawatan } \\
\text { metode } \\
\text { kanguru } \\
\text { terhadap } \\
\text { stres } \\
\text { fisiologis } \\
\text { pada bayi } \\
\text { berat lahir } \\
\text { rendah di } \\
\text { RSUD } \\
\text { Sukoharjo }\end{array}$ & $\begin{array}{l}\text { quasi } \\
\text { eksperi } \\
\text { ment } \\
\text { dengan } \\
\text { desain } \\
\text { peneliti } \\
\text { an } \\
\text { kuantit } \\
\text { atif } \\
\text { dengan } \\
\text { pendek } \\
\text { atan } \\
\text { pre dan } \\
\text { post } \\
\text { test } \\
\text { without } \\
\text { control } \\
\text { group. }\end{array}$ & $\begin{array}{l}48 \text { bayi } \\
\text { BBLR }\end{array}$ & $\begin{array}{l}\text { Purposive } \\
\text { sampling }\end{array}$ & & KMC & 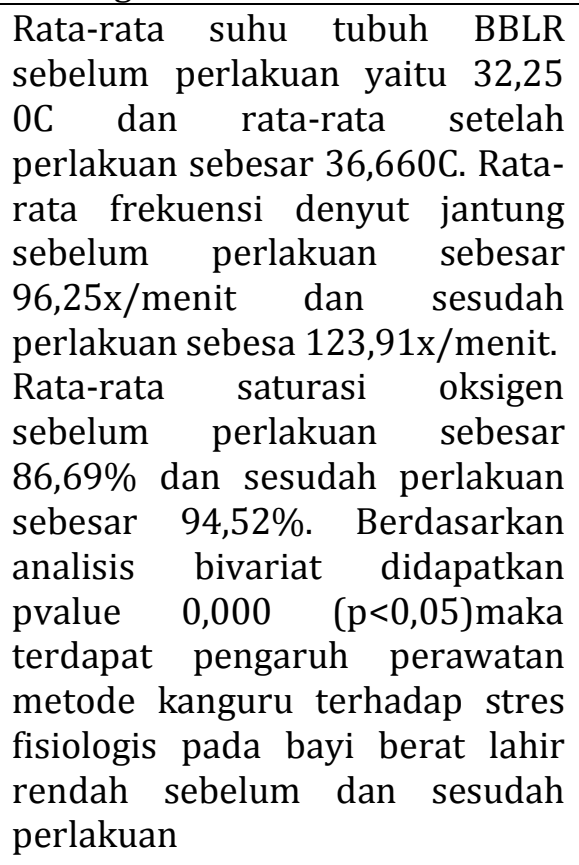 & $\begin{array}{l}\text { Terdapat } \\
\text { pengaruh } \\
\text { perawatan } \\
\text { metode kanguru } \\
\text { terhadap stress } \\
\text { fisilogis pada } \\
\text { bayi berat lahir } \\
\text { rendah sebelum } \\
\text { dan sesudah } \\
\text { dilakukan } \\
\text { perawatan } \\
\text { dengan metode } \\
\text { kanguru di RSUD } \\
\text { Sukoharjo }\end{array}$ & $\begin{array}{l}\text { Lembar } \\
\text { observasi } \\
\text { suhu, } \\
\text { denyut } \\
\text { jantung, } \\
\text { dan } \\
\text { saturasi } \\
\text { oksigen. }\end{array}$ \\
\hline $\begin{array}{l}\text { Armi } \\
\text { (2015) }\end{array}$ & $\begin{array}{l}\text { Pengaruh } \\
\text { perawatan } \\
\text { metode }\end{array}$ & $\begin{array}{l}\text { Quasi } \\
\text { eksperi } \\
\text { mental }\end{array}$ & $\begin{array}{l}5 \text { bayi } \\
\text { dengan } \\
\text { BBLR }\end{array}$ & $\begin{array}{l}\text { Total } \\
\text { populasi }\end{array}$ & $\begin{array}{l}\text { Usia bayi } \\
0-28 \text { hari, } \\
\text { BBLR }\end{array}$ & KMC & $\begin{array}{l}\text { Rata-rata usia ibu dengan bayi } \\
\text { BBLR terpasang alat medis yaitu } \\
29 \text { tahun dengan standar deviasi }\end{array}$ & $\begin{array}{l}\text { Terdapat } \\
\text { pengaruh antara } \\
\text { berat badan bayi }\end{array}$ & \\
\hline
\end{tabular}




\begin{tabular}{|c|c|c|c|c|c|c|c|c|c|}
\hline $\begin{array}{c}\text { Nama } \\
\text { (Tahun) }\end{array}$ & Judul & Metode & Sampel & $\begin{array}{c}\text { Teknik } \\
\text { sampling }\end{array}$ & $\begin{array}{c}\text { Kriteria } \\
\text { Inklusi }\end{array}$ & Perlakuan & Hasil & Kesimpulan & $\begin{array}{c}\text { Instrume } \\
\mathbf{n}\end{array}$ \\
\hline & $\begin{array}{l}\text { kanguru } \\
\text { dengan } \\
\text { inkubator } \\
\text { terhadap } \\
\text { berat } \\
\text { badan bayi } \\
\text { baru lahir } \\
\text { rendah } \\
\text { (BBLR) } \\
\text { yang } \\
\text { terpasang } \\
\text { alat medis } \\
\text { di ruang } \\
\text { perina A } \\
\text { dan NICU } \\
\text { rumah } \\
\text { sakit } \\
\text { umum } \\
\text { kabupaten } \\
\text { Tangerang } \\
2015\end{array}$ & $\begin{array}{l}\text { design. } \\
\text { Penguk } \\
\text { uran } \\
\text { dilakuk } \\
\text { an } \\
\text { sebanya } \\
\text { k } 3 \text { kali } \\
\text { yaitu } \\
\text { sebelu } \\
\text { m } \\
\text { perlaku } \\
\text { an, } \\
\text { setelah } \\
5 \\
\text { dan hari } \\
\text { setelah } \\
10 \text { hari } \\
\text { perlaku } \\
\text { an }\end{array}$ & & & $\begin{array}{l}\text { dengan } \\
\text { berat } \\
\text { kurang } \\
\text { dari 2500 } \\
\text { gram, } \\
\text { terpasan } \\
\text { g alat } \\
\text { mendis } \\
\text { (alat } \\
\text { bantu } \\
\text { napas } \\
\text { CPAP, } \\
\text { infus, } \\
\text { selang } \\
\text { oksigen) }\end{array}$ & & $\begin{array}{l}4,970 \text { tahun. Usia termuda } 24 \\
\text { tahun dan usia tertua } 37 \text { tahun. } \\
\text { Paritas ibu lebih }<3 \text { anak } \\
\text { sebanyak } 60 \% \text {, berada pada } \\
\text { lingkungan baik sebanyak } 61 \\
\text { responden }(67,8 \% \text { ). } \\
\text { Pendidikan ibu berpendidikan } \\
\text { SMP sebanyak } 60 \% \text {. } \\
\text { Rata-rata BB lahir bayi BBLR } \\
\text { terpasang alat medis yaitu } 1860 \\
\text { gram dengan standar deviasi } \\
466,905 \text { gram. berat bayi lahir } \\
\text { minimum } 2400 \text { gram. } \\
\text { Berat badan sebelum dilakukan } \\
\text { perawatan metode kanguru yaitu } \\
1641 \text { dengan standar deviasi } \\
541,13 \text { dan standar eror } 241,9 . \\
\text { Berat badan sesudah dilakukan } \\
\text { perawatan metode kanguru yaitu } \\
1496 \text { dengan standar deviasi } \\
406,485 \text { dan standar eror } \\
181,786 \text {. } \\
\text { Pengaruh berat badan bayi baru } \\
\text { lahir rendah yang terpasang alat } \\
\text { medis terhadap perawatan } \\
\text { metode kanguru dengan nilai } \\
\text { p=0,000 (p<0,05) yang artinya } \\
\text { ada perbedaan yang signifikan }\end{array}$ & $\begin{array}{l}\text { sebelum dan } \\
\text { sesudah } \\
\text { perawatan } \\
\text { dengan metode } \\
\text { kanguru }\end{array}$ & \\
\hline
\end{tabular}




\begin{tabular}{|c|c|c|c|c|c|c|c|c|c|}
\hline $\begin{array}{l}\text { Nama } \\
\text { (Tahun) }\end{array}$ & Judul & Metode & Sampel & $\begin{array}{c}\text { Teknik } \\
\text { sampling }\end{array}$ & $\begin{array}{c}\text { Kriteria } \\
\text { Inklusi }\end{array}$ & Perlakuan & Hasil & Kesimpulan & $\begin{array}{c}\text { Instrume } \\
n\end{array}$ \\
\hline & & & & & & & $\begin{array}{l}\text { antara berat badan bayi pada } \\
\text { sebelum dilakukan perawatan } \\
\text { metode kanguru dengan sesudah } \\
\text { dilakukan perawatan metode } \\
\text { kanguru. }\end{array}$ & & \\
\hline $\begin{array}{l}\text { Fatta } \\
\text { Huniyah } \\
\text { (2018) }\end{array}$ & $\begin{array}{l}\text { Pengaruh } \\
\text { penerapan } \\
\text { metode } \\
\text { kanguru } \\
\text { terhadap } \\
\text { peningkata } \\
\text { n berat } \\
\text { badan bayi } \\
\text { baru lahir } \\
\text { rendah } \\
\text { (BBLR) di } \\
\text { RSI } \\
\text { Sakinah } \\
\text { Mojokerto }\end{array}$ & $\begin{array}{l}\text { pra } \\
\text { eksperi } \\
\text { men } \\
\text { dengan } \\
\text { type } \\
\text { one } \\
\text { group } \\
\text { pre post } \\
\text { test } \\
\text { design } \\
\text { Diuji } \\
\text { dengan } \\
\text { menggu } \\
\text { nakan } \\
\text { uji } \\
\text { paired } \mathrm{t} \\
\text { test }\end{array}$ & $\begin{array}{l}\text { bayi } \\
\text { dengan } \\
\text { BBLR di } \\
\text { RSI } \\
\text { Sakinah } \\
\text { Mojoke } \\
\text { rto } \\
\text { sebanya } \\
\text { k } 11 \\
\text { bayi } \\
\text { lahir } \\
\text { dengan } \\
\text { berat } \\
\text { badan } \\
\text { rendah }\end{array}$ & $\begin{array}{l}\text { concecutiv } \\
\text { e sampling }\end{array}$ & & KMC & $\begin{array}{l}\text { Sebagian besar bayi berjenis } \\
\text { kelamin perempuan sebanyak } 7 \\
\text { responden }(63,6 \%) \text { dan yang } \\
\text { berjenis kelamin laki-laki } \\
\text { sebanyak } 4 \text { responden }(36,4 \%) \text {. } \\
\text { Berdasarkan hasil uji analisis } \\
\text { terdapat perubahan berat badan } \\
\text { setelah diberikan metode } \\
\text { kangguru selama satu bulan dan } \\
\text { seluruh responden mengalami } \\
\text { peningkatan berat badan yang } \\
\text { berkisar antara } 50-350 \text { gram. } \\
\text { Hasil uji paired test diperoleh } \\
\text { nilai } \rho=0 \text {, 000 dan } \alpha=0,05 \\
\text { sehingga } \rho<\alpha \text { maka terdapat } \\
\text { pengaruh penerapan metode } \\
\text { kangguru terhadap peningkatan } \\
\text { berat badan pada bayi BBLR di } \\
\text { Ruang Hasyim Asy'ari RSI } \\
\text { Sakinah Mojokerto Bulan Juli } \\
2017 . \quad \text { Ba }\end{array}$ & $\begin{array}{l}\text { Terdapat } \\
\text { pengaruh } \\
\text { penerapan } \\
\text { metode kangguru } \\
\text { terhadap } \\
\text { peningkatan } \\
\text { berat badan pada } \\
\text { bayi BBLR di } \\
\text { Ruang Hasyim } \\
\text { Asy'ari } \\
\text { Sakinah } \\
\text { Mojokerto Bulan } \\
\text { Juli } 2017\end{array}$ & $\begin{array}{l}\text { lembar } \\
\text { observasi }\end{array}$ \\
\hline $\begin{array}{l}\text { Bera, et al } \\
(2014)\end{array}$ & $\begin{array}{lr}\text { Effect } & \text { of } \\
\text { KMC } & \text { on } \\
\end{array}$ & $\begin{array}{l}\text { RCT } \\
\text { dengan }\end{array}$ & $\begin{array}{l}500 \\
\text { pasanga }\end{array}$ & $\begin{array}{l}\text { Purposive } \\
\text { sampling }\end{array}$ & & KMC & $\begin{array}{l}\text { Tiga kelompok bayi dgn berat } \\
\text { terendah mendapat perlakuan }\end{array}$ & $\begin{array}{l}\text { Bayi dengan KMC } \\
\text { dengan cepat }\end{array}$ & $\begin{array}{l}\text { Skala } \\
\text { penilaian }\end{array}$ \\
\hline
\end{tabular}




\begin{tabular}{|c|c|c|c|c|c|c|c|c|c|}
\hline $\begin{array}{c}\text { Nama } \\
\text { (Tahun) }\end{array}$ & Judul & Metode & Sampel & $\begin{array}{c}\text { Teknik } \\
\text { sampling }\end{array}$ & $\begin{array}{c}\text { Kriteria } \\
\text { Inklusi }\end{array}$ & Perlakuan & Hasil & Kesimpulan & $\begin{array}{c}\text { Instrume } \\
\mathbf{n}\end{array}$ \\
\hline & $\begin{array}{l}\text { growth } \\
\text { and } \\
\text { developme } \\
\text { nt of low } \\
\text { birthweigh } \\
\text { t babies up } \\
\text { to } 12 \\
\text { months of } \\
\text { age }\end{array}$ & $\begin{array}{l}5 \\
\text { kelomp } \\
\text { ok }\end{array}$ & $\begin{array}{l}\mathrm{n} \text { bayi } \\
\text { dan ibu }\end{array}$ & & & & $\begin{array}{l}\text { KMC, dan dua kelompok lagi } \\
\text { mendapat perawatan } \\
\text { konvensional. Semua bayi } \\
\text { mendapat ASI ekslusif selama } 6 \\
\text { bulan, bayi yang mendapat KMC } \\
\text { sampai dgn } 40 \text { hari ditimbang BB } \\
\text { nya. berat, panjang dan kepala, } \\
\text { dada dan lingkar lengan } \\
\text { dievaluasi saat lahir dan pada } \\
\text { usia } 0,3,6,9 \text { dan } 12 \text { bulan } \\
\text { diperiksa. }\end{array}$ & $\begin{array}{l}\text { mencapai } \\
\text { parameter } \\
\text { pertumbuhan } \\
\text { dibandingkan } \\
\text { dgn kelompok } \\
\text { konvensional }\end{array}$ & $\begin{array}{l}\text { perkemba } \\
\text { ngan } \\
\text { untuk byi } \\
\text { india } \\
\text { (DASII) }\end{array}$ \\
\hline
\end{tabular}

